\title{
KEADILAN RESTORATIF DALAM PUTUSAN PIDANA ANAK
}

\author{
Kajian Putusan Nomor 9/PID.SUS-ANAK/2016/PT.BDG
}

\section{RESTORATIVE JUSTICE IN COURT DECISION ON JUVENILE CRIME}

\author{
An Analysis of Court Decision Number 9/PID.SUS-ANAK/2016/PT.BDG
}

\author{
Hesti Septianita \\ Fakultas Hukum Universitas Pasundan \\ Jl. Lengkong Besar No. 68 Bandung 40261 \\ E-mail: hesti.septianita@unpas.ac.id
}

Naskah diterima: 31 Oktober 2017; revisi: 19 Maret 2018; disetujui 6 Agustus 2018

http://dx.doi.org/10.29123/jy.v11i2.290

\begin{abstract}
ABSTRAK
Tulisan ini merupakan sebuah analisis terhadap Putusan Nomor 9/PID.SUS-ANAK/2016/PT.BDG, yang mengkaji sudah tepat atau tidak putusan yang dijatuhkan oleh hakim pengadilan tingkat banding tersebut dengan konsep restorative justice. Metode penelitian yang digunakan dalam tulisan ini adalah metode yuridis normatif dengan pendekatan deskriptif analitis yang menggambarkan sekaligus menganalisis pertimbangan-pertimbangan yang diambil oleh hakim dalam menjatuhkan putusan. Pertimbangan yang diambil oleh hakim pengadilan tingkat banding yang menguatkan putusan hakim pada pengadilan tingkat pertama merupakan pertimbangan yang tepat di mana hakim memutus perkara dengan mempertimbangkan prinsip-prinsip restorative justice. Hakim tidak hanya mempertimbangkan upaya pemberian efek jera tetapi juga mempertimbangkan kepentingan terbaik bagi anak yang berkonflik dengan hukum dengan memastikan pemenuhan hak atas pendidikan dan menghindarkan anak dari risiko pengaruh buruk yang dapat berujung pada berulangnya tindak pidana, karena dalam isu anak yang berkonflik dengan hukum, pendidikan bagi semua anak tanpa memandang asal, ras, gender, kecacatan atau
\end{abstract}

kemampuan dan layanan kesehatan serta advokasi harus diperhatikan. Sejumlah anak tidak sempat mengenyam pendidikan yang lengkap karena situasi penjara yang tidak memungkinkan untuk memberikan pendidikan bagi warga binaannya.

Kata kunci: pidana anak, pembinaan, restorative justice.

\section{ABSTRACT}

This is an analysis of Court Decision Number 9/PID. SUS-ANAK/2016/PT.BDG, which examines whether the decision imposed by the appellate court judge using the restorative justice concept is appropriate. Research in the analysis use normative juridical method with analytical descriptive approach, which describes and analyzes considerations taken by judges in making decision. The consideration taken by the appellate court judge reinforcing the decision of the first-level court judges is the right consideration since the judge decides the case by taking heed to the principles of restorative justice. The judge does not only weigh on the effort to provide a deterrent effect, but also the best interests of children in conflict with the law by ensuring the fulfillment of the children's educational rights and prevent them from the 
risk of bad influences that may lead to the recurrence of crime. Because in the issue of children in conflict with the law, education for all children regardless of origin, race, gender, disability or ability and health services and advocacy should be taken into account. The children are

\section{PENDAHULUAN}

\section{A. Latar Belakang}

Anak sebagai penerus garis keturunan keluarga dan bangsa merupakan bagian penting dunia dan harus mendapatkan perhatian yang utama dengan tetap memperhatikan kepentingan terbaik sang anak. Hukum hak-hak anak didefinisikan sebagai pertemuan antara hukum dan kehidupan anak. Termasuk anak yang berkonflik dengan hukum, proses peradilan bagi anak yang berhadapan dengan sistem peradilan pidana, perwakilan yang tepat, dan layanan rehabilitasi yang efektif; perlindungan bagi anak yang diserahkan pada negara, memastikan pendidikan bagi semua anak tanpa memandang asal, ras, gender, kecacatan atau kemampuan dan layanan kesehatan serta advokasi (Kant, 2011: 1).

Tidak sedikit anak harus berhadapan dengan hukum sejak usia yang sangat dini karena melakukan tindak pidana dengan berbagai alasan, dan tidak sedikit juga anak yang harus berakhir memprihatinkan, menghabiskan masa hidupnya di balik tembok penjara, terenggut dari keluarga dan lingkungannya. Beberapa bahkan menjadi "lebih mahir" melakukan tindak pidana. Sejumlah anak tidak sempat mengenyam pendidikan yang lengkap karena situasi penjara yang tidak memungkinkan untuk memberikan pendidikan bagi warga binaannya.

Munculnya pengadilan anak (juvenille court) pertama di daerah Illinois Amerika not able to get an adequate education because of the incapacity of prison conditions to provide education to their inmates.

Keywords: juvenile crime, educational treatment, restorative justice.

Serikat tahun 1899 yang didasarkan pada "asas parens patriae," menandakan bahwa anak patut dilindungi. Parens patriae adalah doktrin yang mengizinkan negara untuk ikut campur dan bertindak sebagai wali anak, orang dengan sakit jiwa, tidak cakap, orang tua jompo atau orang yang cacat yang tidak bisa merawat dirinya sendiri.

Pengadilan Tinggi Bandung yang memeriksa dan mengadili perkara dalam tingkat banding dalam Putusan Nomor 9/PID.SUSANAK/2016/PT.BDG merupakan contoh dari asas parens patriae di atas. Di mana pengadilan sebagai perwakilan negara bertindak sebagai wali anak dengan memutus apa yang tepat untuk dikenakan terhadap anak yang berkonflik dengan hukum.

Pengadilan Tinggi Bandung memeriksa perkara banding anak atas nama DISG yang melakukan tindak pidana pencurian dengan kekerasan. Pada tingkat pertama, pengadilan yang memutus perkara ini adalah Pengadilan Negeri Bale Bandung dengan Putusan Nomor 21/PID.SUS.ANAK/2015/PN.BLB tanggal 7 Januari 2016. Akta permintaan banding yang dibuat oleh penuntut umum tertanggal 8 Januari 2016 dengan Nomor 01/AKTA.PID/2016/ PN.BLB dibuat oleh Panitera Pengadilan Negeri Bale Bandung yang menerangkan bahwa penuntut umum telah mengajukan permintaan banding terhadap Putusan Nomor 21/PID.SUS. ANAK/2015/PN.BLB dan telah diberitahukan 
kepada DISG tanggal 12 Januari 2016. Memori banding dari penuntut umum pada bulan Januari 2016 diterima oleh Kepaniteraan Pengadilan Negeri Bale Bandung pada tanggal 19 Januari 2016.

DISG didakwa bersama-sama dengan $\mathrm{J}$ dan $\mathrm{F}$ (yang belum tertangkap saat putusan dijatuhkan), pada hari Sabtu tanggal 22 Agustus 2015 sekitar pukul 16.00 WIB dan pada hari Jumat tanggal 9 Oktober 2015 sekitar pukul 17.00 WIB, secara melawan hukum merampas dengan kekerasan satu unit sepeda motor merek Yamaha Mio Sour warna biru bernomor polisi W 5138 AG, dan satu unit sepeda motor merek Honda Beat berwarna putih bernomor polisi D $251 \mathrm{KS}$ di Kuburan Cina atau di wilayah Kp. Babakan Pasir Kaliki RT 03 RW 01 Desa Cikadut, Kecamatan Cimenyan, Kabupaten Bandung.

Peristiwa ini berawal ketika SH sedang menunggu SDF yang sedang berbelanja di warung di daerah Kuburan Cina, Kp. Babakan Pasir Kaliki RT 03 RW 01 Desa Cikadut, Kecamatan Cimenyan, Kabupaten Bandung. SH saat itu duduk di atas satu unit sepeda motor merek Honda Beat warna putih bernomor polisi D 251 KS. Tak lama kemudian DISG dan J mendekati SH dan menodongkan sebilah pisau kecil kepada $\mathrm{SH}$, lalu meminta uang sebesar Rp.50.000,. Karena SH tidak mempunyai uang sebanyak yang diminta, DISG dan J kemudian merampas sepeda motor yang sedang diduduki oleh SH. Sepeda motor tersebut kemudian dijual kepada D melalui AB dengan harga Rp.1.500.000,-.

Hari Jumat tanggal 9 Oktober 2015 sekitar pukul 17.00 WIB di lapangan sepak bola Loder di Desa Cimenyan, Kabupaten Bandung, DISG yang saat itu sedang bersama dengan $\mathrm{F}$ melihat YPP sedang mengendarai satu unit sepeda motor merek Yamaha Mio Soul warna biru, bernomor polisi W 5138 AG. DISG dan F lalu mencegat YPP dengan menggunakan sepeda motor Beat tanpa nomor polisi. DISG dan F mendekat YPP dan meminta uang sebesar Rp.10.000,-, namun YPP hanya memberikan uang sebesar Rp.6.000,- DISG kemudian merebut kunci sepeda motor milik YPP dengan alasan meminjam sepeda motor tersebut, tetapi YPP menolaknya dan DISG lalu memukul YPP dengan kepalan tangan namun tidak mengenai YPP. F kemudian menduduki sepeda motor milik YPP dan mengambil paksa motor tersebut. Pada saat DISG mengendarai sepeda motor yang dirampas dari YPP itulah, DISG ditangkap dan kemudian diproses lebih lanjut.

Atas perbuatannya, DISG didakwa dengan ancaman pidana sesuai Pasal 365 ayat (2) KUHP. Penuntut umum dalam surat tuntutan pidananya tertanggal 6 Januari 2016 Nomor Registrasi Perk.PDM-515/CIMAH/12/2015 menuntut agar hakim Pengadilan Negeri Bale Bandung yang memeriksa dan mengadili perkara ini, memutuskan:

1. Menyatakan DISG bersalah secara bersama-sama melakukan tindak pidana pencurian dengan kekerasan sebagaimana dalam dakwaan tunggal Pasal 365 ayat (2) ke-2 KUHP dalam dakwaan tunggal;

2. Menjatuhkan pidana terhadap DISG dengan pidana penjara selama satu tahun dan enam bulan dikurangkan selama terdakwa berada dalam tahanan dengan perintah DISG tetap ditahan;

3. Menetapkan barang bukti berupa:

- $\quad$ satu unit sepeda motor merk Honda Beat warna putih Nomor Polisi D 
$2521 \mathrm{KS}$ dikembalikan kepada yang berhak dan satu buah pisau dapur gagang warna biru dirampas untuk dimusnahkan.

4. Menetapkan agar terdakwa supaya dibebankan membayar biaya perkara sebesar Rp.1.000,--

Tanggal 7 Januari 2016 majelis hakim Pengadilan Negeri Bale Bandung, kemudian dalam Putusan Nomor 21/PID.SUS.ANAK/2015/ PN.BLB memutuskan:

- Menyatakan DISG telah terbukti secara sah dan meyakinkan bersalah melakukan tindak pidana pencurian dengan kekerasan yang dilakukan secara bersama-sama;

- Menjatuhkan pembinaan kepada DISG di atas dalam Lembaga Pendidikan Islam Pondok Pesantren Safinatul Faizin (Fauzan II) di Kampung Bendapari RT/RW 03/01 Desa Najaten, Kecamatan Cibalong, Kabupaten Garut selama satu tahun enam bulan dengan biaya sendiri;

- Menetapkan agar DISG dikeluarkan dari tahanan;

- $\quad$ Menetapkan barang bukti berupa: satu unit sepeda motor merk Honda Beat warna putih Nomor Polisi D 2521 KS dikembalikan kepada pemiliknya; satu buah pisau dapur gagang warna biru, dirampas untuk dimusnahkan.

- Membebankan kepada DISG membayar biaya perkara sejumlah Rp.1.000,-.

Permintaan banding kemudian diajukan oleh penuntut umum melalui memori banding dengan Nomor 01/AKTA.PID/2016/PN.BLB tanggal 8 Januari 2016 di mana penuntut umum mengemukakan hal-hal berikut:

- Bahwa penuntut umum tidak sependapat dengan putusan yang dijatuhkan hakim tingkat pertama;

Bahwa dalam kasus ini hukuman yang lebih tepat adalah perampasan kemerdekaan yakni pidana satu tahun enam bulan dengan perintah tetap ditahan, oleh karenanya putusan Pengadilan Negeri Bale Bandung adalah keliru;

Bahwa hakim tingkat pertama hanya mempertimbangkan permohonan anak berhadapan dengan hukum tanpa mempertimbangkan sisi lainnya.

Permintaan banding ini disampaikan kepada DISG tanggal 12 Januari 2016 dan diterima oleh Kepaniteraan Pengadilan Negeri Bale Bandung tanggal 19 Januari 2016. Dalam pertimbangannya hakim tingkat banding sependapat dengan hakim tingkat pertama mengenai penjatuhan pidana, mengingat orang tua DISG bersedia anaknya dimasukkan pada sekolah yang banyak muatan pendidikan rohani di pondok pesantren. Di samping itu hakim pengadilan tingkat banding juga sependapat dengan hakim tingkat pertama yang menyatakan bahwa DISG masih terlalu muda sehingga rentan terpengaruh hal-hal yang negatif jika ditempatkan di Lembaga Pembinaan Khusus Anak.

Hakim tingkat banding juga menimbang bahwa Putusan Nomor 21/PID.SUS. ANAK/2015/PN.BLB dapat dipertahankan dan dikuatkan; selain itu mempertimbangkan bahwa karena DISG terbukti bersalah, maka biaya dalam tingkat banding dibebankan kepadanya. Hakim uunggal Pengadilan Tinggi Jawa Barat, dalam 
Putusan Nomor 9/PEN/PD.SUS-ANAK/2016/ PT.BDG tanggal 25 Februari 2016 mengadili sebagai berikut:

1. Menerima permintaan banding dari penuntut umum;

2. Menguatkan Putusan Pengadilan Negeri Bale Bandung tanggal 7 Januari 2016 Nomor 21/PID.SUS.ANAK/2015/PN.BLB yang dimohonkan banding;

3. Membebankan biaya perkara dalam tingkat banding kepada DISG sebesar Rp.2.500,-.

\section{B. RUMUSAN MASALAH}

Berdasarkan pemaparan di atas, rumusan masalah yang dikemukakan dalam tulisan ini adalah:

1. Apakah pertimbangan-pertimbangan yang diambil oleh hakim pengadilan tingkat banding dalam menjatuhkan putusan sudah tepat?

2. Apakah putusan yang diambil oleh hakim sudah mencerminkan restorative justice bagi anak?

\section{TUJUAN DAN KEGUNAAN}

Tulisan ini bertujuan untuk mengkaji dan menganalisis pertimbangan yang diambil oleh hakim Pengadilan Tinggi Jawa Barat untuk menerapkan konsep restorative justice dalam menjatuhkan putusan dalam perkara anak, dan juga untuk mengkaji apakah putusan hakim telah mencerminkan restorative justice bagi anak.

Kegunaan secara teoritis, diharapkan hasil penelitian ini dapat menjadi sumbangan bagi perkembangan ilmu hukum, khususnya hukum pidana anak yang berkaitan dengan pemidanaan. Kegunaan secara praktis, diharapkan hasil penelitian ini dapat memberikan sumbangan kepada para hakim, khususnya hakim anak dalam mengadili perkara anak dengan tetap memperhatikan kepentingan terbaik anak.

\section{TINJAUAN PUSTAKA}

\section{Anak yang Berkonflik dengan Hukum}

Anak menurut Wadong (Susanto, 2011: 78-79) dalam pemaknaan yang umum mendapatkan perhatian tidak saja dalam bidang ilmu pengetahuan (the body of knowledge), tetapi dapat ditelaah dalam sisi pandang sentralistis kehidupan seperti agama, hukum, dan sosiologi yang menjadikan pengertian anak semakin rasional dan aktual dalam lingkungan sosial. Anak diletakkan dalam lingkungan sosial, anak diletakkan dalam advokasi, dan hukum perlindungan anak menjadi objek dan subjek hukum positif yang mengatur tentang anak. Pengelompokan status hak-hak anak dimulai dari sistematika yang mendasar dalam advokasi dari hukum perlindungan anak secara transparan.

Berbicara tentang anak, hukum hakhak anak didefinisikan Kant (2011: 1) sebagai pertemuan antara hukum dan kehidupan anak. Termasuk anak yang berkonflik dengan hukum, proses peradilan bagi anak yang berhadapan dengan sistem peradilan pidana, perwakilan yang tepat, dan layanan rehabilitasi yang efektif; perlindungan bagi anak yang diserahkan pada negara, memastikan pendidikan bagi semua anak tanpa memandang asal, ras, gender, kecacatan atau kemampuan dan layanan kesehatan serta advokasi.

Masalah penanganan anak yang berkonflik dengan hukum sudah muncul sejak lama dalam 
perangkat hukum internasional. Deklarasi Universal tentang Hak Asasi Manusia tahun 1948; Kovenan Internasional mengenai HakHak Ekonomi, Sosial dan Budaya; dan Kovenan Internasional mengenai Hak-Hak Sipil dan Politik telah membahas mengenai hak-hak dan keberadaan serta keselamatan individu-individu muda.

Resolusi PBB Nomor 34/180 tanggal 18 Desember 1979, tentang Convention on the Elimination of All Forms of Discrimination Against Women (CEDAW) yang berlaku tahun 1981 telah membahas hak-hak anak perempuan jauh sebelum Konvensi Hak-Hak Anak dan beberapa instrumen hukum internasional lainnya diberlakukan. Perlindungan ini juga tidak terbatas pada anak-anak yang berkonflik dengan hukum, tetapi juga bagi mereka yang ditelantarkan, mengalami tindak kekerasan, korban penyalahgunaan narkotika, dan yang berada dalam situasi marjinal dan berisiko sosial (Riyadh Guidelines) (Aviandari \& Septianita, $2016: 55)$.

Konvensi Hak Anak (Convention on the Rights of the Child) mendefinisikan anak dalam Pasal 1 sebagai berikut: "Every human being below the age of eighteen years, unless under the law applicable to the child, majority is attained earlier." Di mana anak didefinisikan dengan "setiap manusia yang berusia di bawah delapan belas tahun, kecuali ditentukan lain oleh hukum yang diberlakukan terhadap anak."

Pasal 1 angka 3 Undang-Undang Nomor 11 Tahun 2012 tentang Sistem Peradilan Pidana Anak, menyebutkan anak dimaknai dengan “Anak yang berkonflik dengan hukum yang selanjutnya disebut anak adalah anak yang telah berumur dua belas tahun, tetapi belum berumur delapan bela tahun yang diduga melakukan tindak pidana."

\section{Sistem Pemidanaan Anak}

Secara global, jumlah anak yang dirampas kemerdekaannya sebagai akibat dari berkonflik dengan hukum diperkirakan tidak kurang dari satu juta anak. Anak-anak ini berhadapan dengan penegak hukum berdasarkan sejumlah alasan. Tindak pidana, termasuk tindak pidana politik dan tindak pidana tertentu yang berkaitan dengan anak adalah salah satu alasan mereka berkonflik dengan hukum. Sejumlah anak ditangkap dan ditahan akibat melakukan berbagai risiko kejahatan atau berada dalam situasi yang tidak lazim. Mereka bahkan ditahan karena para penegak hukum salah mengambil tindakan. Akar sosial yang membawa anak-anak ini berkonflik dengan hukum di antaranya adalah kemiskinan, kondisi rumah yang berantakan, kurangnya pendidikan dan peluang kerja, migrasi, narkotika, tekanan teman sebaya, kurangnya bimbingan orang tua, kekerasan, dan eksploitasi (Yuster et al., 2006: 1).

Gönczöl berpendapat bahwa hukum pidana dan aparat penegak hukum tidak boleh bekerja hanya untuk pencapaian kualitas keadilan yang lebih tinggi melainkan untuk tujuan aktual. Aparat penegak hukum harus menyasar jaminan keamanan dan kedamaian di masyarakat atau memulihkannya jika harus, oleh karenanya fungsi dari hukum pidana tidak semata-mata pemenuhan 'rasa keadilan.' Untuk memulihkan kedamaian sosial, hukum pidana harus menjunjung penegakan hak kebebasan yang dilanggar oleh suatu tindak pidana. Peradilan pidana harus menegakkan keadilan bagi merekamereka yang terlibat dalam suatu konflik, baik itu pelaku maupun korban sehingga norma dan moral yang terkandung di dalamnya menjadi kuat. Pada saat yang bersamaan, peradilan pidana dalam kerangka rule of law memenuhi tujuan pencegahannya atau paling tidak berkontribusi 
pada pencegahan munculnya konflik yang sama dan kemungkinan berulangnya pelaku atau korban (Gönczöl et al., 2010: 3).

Anak yang berkonflik dengan hukum yang telah berusia dua belas tahun dapat dikenakan proses hukum. Hal ini disiratkan dalam konstruksi Pasal 1 angka 3 Undang-Undang Nomor 11 Tahun 2012 tentang Sistem Peradilan Pidana Anak, oleh karenanya hakim dapat menjatuhkan pidana penjara atau tindakan/pembinaan seperti yang diatur dalam Pasal 71 ayat (1) dan (2) UndangUndang Nomor 11 Tahun 2012, yaitu:

(1) Pidana pokok bagi Anak terdiri atas:

a. pidana peringatan;

b. pidana dengan syarat:

1) pembinaan di luar lembaga;

2) pelayanan masyarakat; atau

3) pengawasan.

c. pelatihan kerja;

d. pembinaan dalam lembaga;

e. penjara.

(2) Pidana tambahan terdiri atas:

a. perampasan keuntungan yang diperoleh dari tindak pidana; atau

b. pemenuhan kewajiban adat.

Plato (427-347 SM) menggambarkan dalam tulisannya Laws, bahwa anak yang melanggar hukum akan menjalani hukuman yang singkat di dalam sebuah gedung milik publik di dekat pasar; sedangkan pelaku kejahatan yang serius tetapi masih bisa ditebus akan menjalani hukuman yang lebih lama dan dikirim ke pusat perbaikan diri terdekat; sedangkan mereka yang tidak bisa diperbaiki lagi pribadinya akan dikurung dalam sebuah penjara yang dijaga ketat yang jauh dari kota. Cetak biru dari ide Plato ini tidak pernah diadopsi oleh orang-orang Yunani Kuno, tetapi ia menggambarkan sebuah akurasi yang luar biasa dari sebuah sistem penjara yang berorientasi pemasyarakatan berabad-abad sesudahnya dengan tingkat keamanan yang berbeda-beda (Kurian, 2006: 76).

Metode yang popular dalam penegakan hukum menurut Wamsley adalah pemenjaraan, dan karenanya semakin banyak orang yang dikirim ke penjara daripada sebelumnya, namun pendapat lain menyatakan bahwa pengalaman yang didapat dari pemenjaraan itu dikarakteristikan dengan 'rasa sakit' dan 'pencabutan kemerdekaan. Lebih lagi menurut Gendreau, Goggin dan Cullen hanya sedikit bukti yang menunjukkan penurunan langsung jumlah kejahatan dengan digunakannya metode pemenjaraan yang kemudian menggarisbawahi efek jera yang terbatas. Bahkan Losel memperkuat pernyataan di atas dengan menunjukkan bahwa hanya sedikit program yang berdampak positif bagi pelaku, dengan demikian membatasi dampak rehabilitatif dari pemenjaraan.(Dhami et al., 2009: 433-448)

\section{Restorative Justice Bagi Anak yang Berkonflik dengan Hukum}

Konvensi Hak Anak sangat mendorong asas kepentingan terbaik bagi anak dalam setiap tindakan yang diambil terhadap anak, terutama dalam pelaksanaan peradilan pidana anak. Asas ini penting karena anak mempunyai kebutuhan fisik, psikologis, emosi, dan pendidikan yang berbeda dari orang dewasa. Menurut Komite Hak Anak, anak harus diperlakukan berbeda dalam sistem peradilan pidana dan harus mengacu pada reintegrasi sosial serta penerapan prinsip-prinsip restorative justice. 
Restorative justice atau keadilan restoratif atau keadilan pemulihan merupakan pendekatan terhadap peradilan pidana yang menekankan pemulihan korban dan komunitas ketimbang menghukum pelaku tindak pidana. The Restorative Justice Consortium memberikan definisi keadilan restoratif sebagai berikut: "Restorative justice works to resolve conflict and repair harm. It encourages those who have caused harm to acknowledge the impact of what they have done and gives them an opportunity to make reparation. It offers those who have suffered harm the opportunity to have their harm or loss acknowledged and amends made" (Liebmann, 2007: 25).

Restorative justice atau yang dikenal juga dengan keadilan yang memulihkan diartikan sebagai sarana untuk menyelesaikan konflik dan memperbaiki kerusakan dengan mendorong pihak-pihak yang menyebabkan kerusakan untuk mengakui dampak dari apa yang sudah dilakukan dan memberikan kesempatan untuk melakukan perbaikan. Di sisi lain, menawarkan kepada korban untuk mengganti dan merubah kerusakan atau kerugian yang dialami. Walaupun konsep restorative justice seringkali diajukan sebagai sebuah alternatif bagi sistem peradilan pidana tradisional, tetapi konsep ini semakin dipandang ampuh seperti yang dikemukakan oleh Immarigeon, Lee, Robert, dan Hough (Dhami et al., 2009: 433-448) .mengemukakan bahwa program restorative justice ada di beberapa tahap berbeda dalam proses peradilan pidana seperti pra-penyidikan, pasca penyidikan, prapenuntutan, pasca penuntutan, dan pra-putusan atau pasca putusan, dan lain-lain

Prinsip-prinsip yang dianut dalam pendekatan keadilan restoratif (Liebmann, 2007: 28) adalah: a. Memprioritaskan dukungan dan pemulihan korban.

Walaupun dukungan dan pemulihan tampaknya jelas menjadi tujuan sistem peradilan pidana, namun dengan menjadikannya prioritas akan membuat sistem menjadi lebih kuat. Hal ini dikarenakan bahwa hampir kebanyakan dari sistem peradilan pidana berfokus pada pelaku—mengidentifikasi, menangkap, memproses secara pidana, mengadili, menghukum, dan memenjarakan mereka. Semua penegak hukum keberadaannya hanya untuk pelaku. Walaupun kebutuhan korban sudah mulai diakui, tetapi masih sangat tidak seimbang dengan sumber daya yang dialokasikan.

b. Pelaku bertanggung jawab atas apa yang telah mereka lakukan.

Pelaku biasanya 'menerima hukuman' tetapi maknanya berbeda dengan 'bertanggung jawab' terhadap apa yang telah mereka lakukan. Menyadari bahwa pelaku bertanggung jawab atas apa yang telah dilakukan merupakan titik awal dari keadilan restoratif.

c. Dialog untuk mencapai pemahaman.

Dialog antara pelaku dan korban menjadi penting karena merupakan salah satu proses utama dalam keadilan restoratif. Dialog ini tidak mungkin dilakukan dalam proses formal di pengadilan.

d. Adanya upaya untuk memperbaiki kerugian yang terjadi.

Bertanggung jawab terhadap kerugian yang ditimbulkan adalah mencoba memperbaiki 
sebisa mungkin. Terkadang permintaan maaf sudahlah cukup, tetapi seringkali memerlukan sesuatu lebih.

e. Pelaku berusaha menghindari melakukan tindakan pidana lagi di kemudian hari.

Ketika pelaku telah menyadari kesalahan yang telah ia lakukan, mereka biasanya tidak ingin mengulang perilaku mereka. Terkadang ini cukup untuk menghentikan mereka melakukan tindak pidana. Poin penting dari pendekatan restoratif adalah mempertemukan korban dan pelaku untuk memberikan motivasi untuk tidak mengulang melakukan tindak pidana.

f. Masyarakat membantu proses reintegrasi korban dan pelaku.

Seringkali sangat jelas bahwa pelaku perlu bereintegrasi ke dalam masyarakat, utamanya setelah menjalani pidana penjara-mereka memerlukan akomodasi, pekerjaan, dan hubungan untuk menjadi anggota positif masyarakat. Korban juga perlu bereintegrasi ke dalam masyarakat karena mereka seringkali merasa terkucilkan dan terasing akibat kejahatan yang dialaminya.

Instrumen hukum nasional Indonesia sudah memasukkan restorative justice sebagai bagian tidak terpisahkan dari sistem peradilan pidana anak. Pasal 1 angka 6 Undang-Undang Nomor 11 Tahun 2012 menyebutkan:

"Keadilan restoratif adalah penyelesaian perkara tindak pidana dengan melibatkan pelaku, korban, keluarga pelaku/korban, dan pihak lain yang terkait untuk bersama-sama mencari penyelesaian yang adil dengan menekankan pemulihan kembali pada keadaan semula, dan bukan pembalasan."
Undang-undang ini mengatur bahwa keseluruhan sistem peradilan pidana anak wajib mengutamakan pendekatan keadilan restoratif dalam setiap tingkatan peradilan, mulai dari tahap penyidikan, penuntutan, persidangan, hingga proses pembinaan, pembimbingan, pengawasan, dan pendampingan saat anak menjalani pelaksanaan pidana/tindakan. Tidak hanya itu, pendekatan keadilan restoratif juga menjadi acuan pembinaan anak setelah menjalani masa pidana/tindakan.

Tujuan utama dari pendekatan keadilan restoratif menurut Aviandari \& Septianita (2016: 4) adalah tercapainya pemulihan kembali, baik korban, pelaku maupun tatanan sosial yang sempat terganggu karena tindakan yang dilakukan oleh pelaku kejahatan, karena itu penyelesaian kasus difokuskan pada bagaimana memulihkan penderitaan, kerusakan atau kerugian yang timbul, bukan membalas atau menggantikan penderitaan, kerusakan atau kerugian dari korban dengan penderitaan (pemidanaan) pelaku.

Restitusi sebagai suatu sarana untuk memperbaiki kondisi (korban) menjadi relevan diterapkan, walau tidak menjadi tujuan utama. Melalui pendekatan keadilan restoratif, pelaku dipulihkan dengan diberi ruang untuk menyadari kesalahannya, mempertanggungjawabkan perbuatannya, serta memulihkan kerusakan atau kerugian yang ditimbulkan tanpa harus diwujudkan dalam bentuk pemidanaan. Untuk lebih jelasnya, berikut adalah prinsip-prinsip yang membandingkan fokus perhatian pada sistem peradilan pidana yang tradisional dengan sistem restoratif.

Terkait anak yang berkonflik dengan hukum, Konvensi Hak Anak dalam Pasal 37 huruf a memberikan jaminan bahwa anak tidak boleh 
Tabel 1. Perbedaan Sistem Peradilan Pidana Retributif dan Restoratif

Paradigma Lama: Retributif

Paradigma Baru: Restoratif

\begin{tabular}{|c|c|}
\hline Fokus pada kesalahan dan rasa bersalah. & $\begin{array}{l}\text { Fokus pada pemecahan masalah, tanggung jawab, dan } \\
\text { kewajiban, fokus pada masa depan. }\end{array}$ \\
\hline Stigma kejahatan bersifat permanen. & Stigma kejahatan bisa dihilangkan. \\
\hline Tidak ada dorongan untuk menyesal dan memaafkan. & Memungkinkan adanya penyesalan dan memaafkan. \\
\hline $\begin{array}{l}\text { Ketergantungan pada orang-orang profesional yang } \\
\text { mewakili. }\end{array}$ & Keterlibatan langsung para pihak. \\
\hline $\begin{array}{l}\text { Tindakan diarahkan oleh negara kepada pelaku: Korban } \\
\text { terabaikan-pelaku pasif. }\end{array}$ & $\begin{array}{l}\text { Peran korban dan pelaku diakui baik dalam permasalahan } \\
\text { dan solusi: hak/kebutuhan korban diakui; pelaku didorong } \\
\text { untuk bertanggung jawab. }\end{array}$ \\
\hline $\begin{array}{l}\text { Akuntabilitas pelaku didefinisikan dengan menerima } \\
\text { hukuman. }\end{array}$ & $\begin{array}{l}\text { Akuntabilitas pelaku diartikan dengan memahami dampak } \\
\text { dari tindakan yang dilakukan dan membantu menentukan } \\
\text { bagaimana memperbaikinya. }\end{array}$ \\
\hline $\begin{array}{l}\text { Tindak pidana didefinisikan murni sebagai istilah hukum } \\
\text {-kurangnya dimensi moral, sosial, ekonomi, politik. }\end{array}$ & $\begin{array}{l}\text { Tindak pidana dipahami dalam konteks yang utuh -moral, } \\
\text { sosial, ekonomi, politik. }\end{array}$ \\
\hline $\begin{array}{l}\text { "Hutang" yang harus dibayarkan kepada negara dan } \\
\text { masyarakat. }\end{array}$ & Hutang/tanggung jawab terhadap korban diakui. \\
\hline Respon difokuskan pada perilaku masa lalu pelaku. & $\begin{array}{l}\text { Respon difokuskan pada konsekuensi yang merugikan } \\
\text { dari perilaku pelaku. }\end{array}$ \\
\hline $\begin{array}{l}\text { Membebankan untuk menghukum dan menjerakan/ } \\
\text { mencegah. }\end{array}$ & Kejahatan dilihat sebagai konflik interpersonal. \\
\hline Masyarakat diwakili secara abstrak oleh negara. & Masyarakat sebagai fasilitator. \\
\hline
\end{tabular}

Sumber: The Canadian Resource Center for Victim of Crime (2011)

mendapatkan penyiksaan atau perlakuan kejam, tidak manusia, dan merendahkan martabat. Pasal 40 konvensi ini juga menegaskan bahwa usia anak harus menjadi pertimbangan dan setiap rencana atas tindakan apa yang akan dikenakan terhadap anak harus mendorong mereka untuk dapat berintegrasi ke dalam masyarakat.

Menurut Aviandari \& Septianita, berbagai kajian menunjukkan bahwa pendekatan keadilan restoratif memberi manfaat bagi korban dan keluarga korban. Pertama, korban akan terhindar daritekanan psikologis selama proses pemeriksaan polisi, jaksa hingga pengadilan. Proses peradilan pidana, disukai atau tidak, mengharuskan korban untuk menceritakan berulang kali kejadian tidak menyenangkan yang dialaminya. Proses pemeriksaan berpotensi besar memperburuk tekanan psikologis yang dialami korban, terutama korban-korban kejahatan seksual. Kedua, korban dan keluarga korban terhindar dari proses peradilan yang cenderung menyita energi, waktu, dan perhatian. Ketiga, korban dan keluarga diberi ruang untuk mengemukakan pendapatnya tentang cara penyelesaian masalah terbaik termasuk pertanggungjawaban pelaku. Dalam sistem peradilan pidana konvensional, otoritas memutus hukuman bagi pelaku hanya ada pada hakim. Keempat, korban dan keluarga diberi ruang untuk meminta ganti kerugian secara langsung, baik materiil maupun immateriil. Keenam, korban dan keluarga terhindar dari pemberitaan yang 
dapat mengganggu psikologis anak (Aviandari \& Septianita, $2016: 4$ ).

Dalam kerangka hukum dan kebijakan nasional, perlakuan terhadap anak yang berkonflik dengan hukum dan sedang menjalani masa pidana tetaplah menggunakan prinsip perlindungan hukum terhadap anak sesuai dengan Konvensi Hak Anak. Pertimbangannya adalah bahwa anak adalah bagian yang tidak terpisahkan dari keberlangsungan hidup manusia dan keberlangsungan sebuah bangsa dan negara. Anak memiliki peran strategis di mana negara menjamin hak setiap anak atas kelangsungan hidup, tumbuh, dan berkembang serta atas perlindungan dari kekerasan dan diskriminasi. Kepentingan terbaik bagi anak, oleh karenanya, harus sekaligus dianggap sebagai kepentingan terbaik bagi kelangsungan hidup umat manusia (Aviandari \& Septianita, 2016: 66).

\section{METODE}

Tulisan ini menggunakan metode penelitian yuridis normatif dengan pendekatan deskriptif analitis yang menggambarkan permasalahan yang diteliti secara detil dan mendalam dengan menggunakan bahan-bahan hukum berupa bahan hukum primer, sekunder, dan tersier. Bahan hukum primer adalah semua aturan hukum yang dibentuk dan/atau dibuat secara resmi oleh suatu lembaga negara, dan/atau badan-badan pemerintahan, yang demi tegaknya akan diupayakan berdasarkan data paksa yang dilakukan secara resmi pula oleh aparat negara.

Bahan hukum sekunder adalah seluruh informasi tentang hukum yang berlaku atau yang pernah berlaku di suatu negeri yang berfungsi sebagai sumber hukum materil yang merupakan informasi yang relevan dengan permasalahan hukum, serta bahan hukum tersier yang difungsikan sebagai sumber referensi (Wigjnosoebroto, 2013: 81-84).

Bahan hukum primer dalam tulisan ini meliputi peraturan perundang-undangan baik peraturan perundang-undangan nasional dan internasional terkait sistem peradilan pidana anak, seperti Undang-Undang Nomor 11 Tahun 2012 tentang Sistem Peradilan Pidana Anak, Undang-Undang Nomor 48 Tahun 2009 tentang Kekuasaan Kehakiman, Guidelines for the Prevention of Juvenile Delinquency (Riyadh Guidelines), The Tokyo Rules (UN Standard Minimum Rules for Non-Custodial Measures), dan Konvensi Hak Anak (UN Convention on the Right of the Child). Bahan-bahan hukum sekunder berupa pendapat para ahli mengenai anak, sistem peradilan pidana anak, dan restorative justice dalam bentuk literatur hukum. Bahan hukum tersier berupa tulisan-tulisan terkait bahasan tentang anak yang berkonflik dengan hukum, sistem peradilan pidana anak serta restorative justice yang diambil dari internet.

Data yang digunakan dalam penelitian ini dikumpulkan menggunakan teknik pengumpulan data secara studi kepustakaan (library research), di mana data tersebut kemudian diolah dan dianalisis untuk menghasilkan kesimpulan yang diambil secara deduktif argumentatif.

III. HASIL DAN PEMBAHASAN

A. Pertimbangan yang Diambil oleh Hakim Pengadilan Tingkat Banding dalam Menjatuhkan Putusan terhadap Perkara Anak

Dalam Putusan Nomor 9/PID.SUSANAK/2016/PT.BDG, hakim menimbang dan sependapat dengan pertimbangan yang diambil 
oleh hakim pengadilan tingkat pertama yang mempertimbangkan usia anak yang berkonflik dengan hukum DISG yang masih sangat muda sehingga dianggap rentan terpengaruh hal-hal negatif selama berada di Lembaga Pembinaan Khusus Anak.

Pertimbangan ini menjadi tepat ketika melihat realitas yang ada di mana tidak sedikit anak harus berhadapan dengan hukum sejak usia yang sangat dini karena melakukan tindak pidana dengan berbagai alasan, dan tidak sedikit juga anak yang harus berakhir memprihatinkan, menghabiskan masa hidupnya di balik tembok penjara, terenggut dari keluarga dan lingkungannya. Beberapa bahkan menjadi "lebih mahir" melakukan tindak pidana. Ironisnya sejumlah anak tidak sempat mengenyam pendidikan yang lengkap karena situasi penjara yang tidak memungkinkan untuk memberikan pendidikan bagi warga binaannya.

Hal di atas sejalan dengan apa yang diungkapkan oleh Crawford dan Newburn (Masahiro \& Hennessey, 2016).yang menyatakan bahwa merupakan sebuah tantangan sejak dulu untuk mengembangkan cara-cara efektif dalam menyikapi tindak pidana. Dalam hal ini, sistem peradilan yang konvensional seringkali dikritisi atas ketidakefektifannya.

Pertimbangan hakim pengadilan tingkat banding yang menguatkan putusan hakim tingkat pertama, yang memutuskan untuk menjatuhkan pembinaan terhadap DISG dalam Lembaga Pendidikan Islam Pondok Pesantren Safinatul Faizin (Fauzan II) di Kampung Bendapari RT/ RW 03/01 Desa Najaten, Kecamatan Cibalong, Kabupaten Garut selama satu tahun dan enam bulan dengan biaya sendiri, merupakan sebuah putusan dengan pertimbangan upaya pemulihan bagi anak tersebut dan merupakan pertimbangan dan putusan yang tepat, ketimbang menjatuhkan pidana perampasan kemerdekaan seperti yang dituntut oleh penuntut umum dalam tuntutannya. Ini dikarenakan pidana penjara harus dikenakan kepada anak sebagai upaya terakhir (ultimum remedium).

Bagi pelaku, yang masih dalam tahap perkembangan menjadi dewasa, pendekatan keadilan restoratif bermanfaat menghindarkan pelaku dari dampak buruk pemenjaraan. Selain itu, pelaku juga akan terhindar dari tekanan psikologis proses pemeriksaan polisi, jaksa hingga pengadilan. Terkait aspek pemulihan, Firdaus (Aviandari \& Septianita, 2016: 4) mengemukakan bahwa melalui pendekatan keadilan restoratif pelaku dan keluarga mendapatkan manfaat, yaitu:

1. Memiliki kesempatan untuk memperbaiki diri;

2. Tetap dalam pengasuhan dan bimbingan orang tua;

3. Memiliki kesempatan untuk mempertanggungjawabkan perbuatan secara langsung kepada korban atau keluarga korban;

4. Memiliki kesempatan untuk mempertanggungjawabkan perbuatan kepada lingkungan masyarakat; dan

5. Terhindar dari pemberitaan yang dapat mengganggu psikologis anak/keluarga.

Setiap langkah yang memungkinkan pencegahan dampak detrimental dari pidana perampasan kemerdekaan anak harus diambil, demikian juga oleh hakim jika anak terlanjur berada dalam sistem peradilan pidana. Inilah yang ditegaskan dalam The Tokyo Rules (UN Standard 
Minimum Rules for Non-Custodial Measures) yang mendorong keterlibatan masyarakat dalam sistem peradilan pidana. Di mana tindakantindakan non-pemenjaraan harus menjadi bagian dari gerakan depenalisasi dan dekriminalisasi serta upaya-upaya reintegrasi dalam masyarakat, sehingga publik bisa turut berpartisipasi dalam upaya mencegah berulangnya tindak pidana.

Hal demikian juga diamanatkan oleh Undang-Undang Nomor 11 Tahun 2012 tentang Sistem Peradilan Pidana Anak di mana penegak hukum, dalam hal ini penuntut umum dan hakim, harus selalu memegang prinsip bahwa pidana penjara terhadap anak hanya digunakan sebagai upaya terakhir.

Menurut Zehr, sistem peradilan pidana anak dipandang naik turun antara model keadilan dan kesejahteraan, antara retribusi dan rehabilitasi (Braithwaite, 2002: 10). Untuk sebagian mereka yang liberal, restorative justice mempunyai daya tarik karena menawarkan konsep sistem peradilan yang tidak selalu menghukum, sedangkan bagi orang-orang konservatif, restorative justice dianggap memberikan tekanan kuat terhadap pemberdayaan korban, keluarga, tanggung jawab keluarga, dan penghematan biaya.

\section{B. Prinsip Restorative Justice dalam Putusan Nomor 9/PID.SUS-ANAK/2016/PT.BDG}

Penjatuhan pembinaan yang diputuskan oleh hakim baik pada pengadilan tingkat pertama maupun hakim pada pengadilan tingkat banding yang menguatkan putusan pengadilan di bawahnya, yang dengan cukup berani menjatuhkan putusan yang berbeda dengan apa yang dituntut oleh penuntut umum, merupakan suatu putusan yang bernuansa restoratif. Hakim di sini jelas menjalankan keharusannya untuk menggali nilai-nilai yang hidup di masyarakat sebelum memutuskan suatu perkara (Pasal 5 ayat (1) Undang-Undang Nomor 48 Tahun 2009 tentang Kekuasaan Kehakiman) selain menjalankan tugasnya untuk menegakkan hukum dan keadilan. Tentu saja dalam memutus perkara, hakim harus merujuk pada undang-undang yang berlaku. Dalam konteks Indonesia, hakim bukanlah corong undang-undang. Hakim adalah corong kepatutan, keadilan, kepentingan umum, dan ketertiban umum. Dalam konteks inilah, rumusan keharusan hakim memperhatikan nilainilai yang hidup dalam masyarakat harus dibaca.

Penjelasan Pasal 5 ayat (1) UndangUndang Nomor 48 Tahun 2009 tentang Kekuasaan Kehakiman menyebutkan ketentuan untuk memperhatikan nilai-nilai yang hidup dalam masyarakat dimaksudkan agar putusan hakim sesuai dengan hukum dan rasa keadilan masyarakat (Hukum Online, 2013). Sistem peradilan pidana anak, berdasarkan Pasal 2 Undang-Undang Nomor 11 Tahun 2012 tentang Sistem Peradilan Pidana Anak, juga mengamanatkan dilaksanakan berdasarkan asas:

1. Perlindungan

2. Keadilan

3. Non diskriminasi

4. Kepentingan terbaik bagi anak

5. Penghargaan terhadap pendapat anak

6. Kelangsungan hidup dan tumbuh kembang anak

7. Pembinaan dan pembimbingan anak Proporsional

8. Perampasan kemerdekaan dan pemidanaan sebagai upaya terakhir, dan 
9. Penghindaraan pembalasan.

Dalam perkara DISG ini, hakim memperhatikan kepentingan terbaik bagi masa depan anak dengan mencegah dampak pemenjaraan yang mungkin membuatnya melakukan kembali tindak pidana. Dalam sistem peradilan pidana anak yang berlaku di Indonesia, Pasal 82 ayat (1) Undang-Undang Nomor 11 Tahun 2012 mengatur jenis-jenis tindakan yang dapat dikenakan kepada anak, yaitu:

1. Pengembalian kepada orang tua/wali;

2. Penyerahan kepada seseorang;

3. Perawatan di rumah sakit jiwa;

4. Perawatan di LPKS;

5. Kewajiban mengikuti pendidikan formal dan/atau pelatihan yang diadakan oleh pemerintah atau badan swasta;

6. Pencabutan surat izin mengemudi; dan/atau

7. Perbaikan akibat tindak pidana.

Undang-undang mengamanatkan pengaturan lebih lanjut terkait ketentuan mengenai jenis tindakan tersebut di atas. Diaturnya berbagai jenis putusan saat hakim harus memutus anak bersalah menunjukkan bahwa Undang-Undang Nomor 11 Tahun 2012 mengandung semangat menjauhkan anak dari penjara.

Hakim diberi ruang untuk memberikan sanksi yang terbaik bagi perkembangan anak. Jika seorang anak diputus dengan pidana penjara maka harus dimaknai bahwa hakim telah mempertimbangkan berbagai jenis tindakan atau pidana lainnya, sebelum pada akhirnya dengan terpaksa memutus pidana penjara (Aviandari \& Septianita, 2016: 28).
Tugas hakim bukan hanya sebagai penerap hukum (undang-undang) atas perkara-perkara di pengadilan atau agent of conflict, tetapi seharusnya juga mencakup penemuan dan pembaruan hukum. Hakim yang ideal, selain memiliki kecerdasan yang tinggi, juga harus mempunyai kepekaan terhadap nilai-nilai keadilan, mampu mengintegrasikan hukum positif ke dalam nilainilai agama, kesusilaan, sopan santun, dan adat istiadat yang hidup dalam masyarakat melalui setiap putusan yang dibuatnya karena pada hakikatnya mahkota seorang hakim itu bukan pada palunya, melainkan pada bobot atau kualitas dari putusan yang dihasilkan (Bram, 2011: 82). Dalam perspektif Bentham, hukum yang bermanfaat ialah yang berdasarkan pada empat tolok ukur utama pemenuhan nilai kemanfaatan, yaitu: menyediakan mata pencaharian, menghasilkan kemakmuran, mengutamakan kesamaan, dan menjaga keamanan (Shidarta, 2007: 39).

Apa yang diputuskan oleh hakim dalam Putusan Nomor 9/PID.SUS-ANAK/2016/ PT.BDG telah memenuhi nilai keadilan dan kemanfaatan yang menjadi poin penting dalam penegakan hukum. Memang selama ini pemenjaraan dipandang sebagai suatu kebijakan atau reaksi terhadap pelaku kejahatan yang diharapkan dapat memunculkan pengaruh deterrence (efek jera) dan special deterrence (mengurangi potensi melakukan tindak pidana (potential offenders).

Perlu diperhatikan bahwa seringkali jumlah anak yang dikirim ke penjara-penjara atau yang sekarang dikenal sebagai Lembaga Pembinaan Khusus Anak berdasarkan Undang-Undang Nomor 11 Tahun 2012 tentang Sistem Peradilan Pidana Anak melebihi jumlah yang dapat ditampung dalam sebuah Lembaga Pembinaan Khusus Anak, sehingga pertimbangan non- 
pemenjaraan harus selalu menjadi prioritas para hakim yang memutus perkara anak.

Setyawan yang berpendapat bahwa penjara hanya tepat untuk orang dewasa yang melakukan kejahatan. Anak tidak tepat masuk penjara karena akan mematikan harapan masa depannya. Anak adalah pribadi otonom yang sedang tumbuh, yang membutuhkan bantuan dan bimbingan. Peradilan yang tepat untuk pelaku delinkuensi (kenakalan) anak adalah model keadilan restoratif yang bersifat memperbaiki dan memulihkan hubungan pelaku dan korban sehingga harmoni kehidupan tetap terjaga. Hukuman maksimal yang boleh mereka terima adalah pendidikan paksa (Setyawan, 2014).

Putusan hakim yang mengirim DISG untuk mendapatkan pembinaan di Lembaga Pendidikan Islam Pondok Pesantren Safinatul Faizin (Fauzan II) di Kampung Bendapari RT/RW 03/01 Desa Najaten, Kecamatan Cibalong, Kabupaten Garut selama satu tahun dan enam bulan dengan biaya sendiri menunjukkan bahwa hakim memperhatikan pendidikan anak. Pertimbangan ini sesuai dengan empat pilar pendidikan yang ditetapkan oleh UNESCO, yaitu:

1. Learning to know (pembelajaran untuk tahu) Menyediakan alat kognitif yang disyaratkan untuk pemahaman yang lebih baik terhadap dunia dan kompleksitasnya dan menyediakan dasar yang tepat dan cukup untuk pembelajaran di masa datang.

2. Learning to do (pembelajaran untuk berbuat) Memberikan keterampilan yang memungkinkan setiap individu untuk berpartisipasi secara efektif dalam ekonomi dan masyarakat global.

3. Learning to be (pembelajaran untuk membangun jati diri)
Memberikan kemampuan sosial dan analisis diri untuk memungkinkan setiap individu untuk mengembangkan potensi penuh individu tersebut secara psikososial, afektif maupun fisik, sebagai manusia yang lengkap.

4. Learning to live together (pembelajaran untuk hidup bersama secara harmonis) Untuk membuat individu terpapar dengan nilai-nilai yang implisit dalam hak asasi manusia, prinsip-prinsip demokrasi, pemahaman interkultural dan saling menghargai dan perdamaian pada semua tingkatan masyarakat dan hubungan manusia agar memungkinkan individu dan masyarakat untuk hidup dalam perdamaian dan harmoni.

\section{KESIMPULAN}

Pertimbangan hakim dalam menjatuhkan putusan yang menyatakan bahwa DISG bersalah secara bersama-sama melakukan tindak pidana "pencurian dengan kekerasan" sebagaimana diatur dan diancam pidana dalam Pasal 365 ayat (2) ke-2 KUHP dan menjatuhkan pembinaan kepada anak dalam Lembaga Pendidikan Islam Pondok Pesantren Safinatul Faizin selama satu tahun dan enam bulan dengan biaya sendiri ketimbang memasukkannya ke dalam penjara dengan alasan bahwa situasi penjara yang malah dikhawatirkan semakin merusak masa depan DISG sudahlah tepat dengan memperhatikan peluang DISG untuk mendapatkan pendidikan dan pendidikan karakter yang diharapkan dapat mencegah berulangnya tindak pidana.

Putusan hakim tersebut tepat di mana hakim tidak semata-mata menjatuhkan hukuman dan mengupayakan efek jera. Walaupun Undang- 
Undang Nomor 11 Tahun 2012 tentang Sistem Peradilan Pidana Anak tidak dijadikan salah satu acuan pertimbangan ketika mengambil dan menjatuhkan pembinaan, namun hakim dalam memutus perkara ini memperhatikan prinsip-prinsip restorative justice seperti yang diamanatkan dalam undang-undang tersebut. Hakim memperhatikan kepentingan terbaik anak dan hak anak untuk mendapatkan pendidikan sekaligus menghindarkan anak dari kemungkinan dampak detrimental bagi anak jika ditempatkan di penjara, serta kemungkinan berulangnya tindak pidana.

\section{DAFTAR ACUAN}

Aviandari, D., \& Septianita, H. (2016). Mengembangkan model pendampingan berlandaskan keadilan restoratif di Lembaga Pembinaan Khusus Anak, kumpulan kajian. Yogyakarta: Yayasan Samin.

Braithwaite, J. (2002). Restorative justice \& responsive regulation. New York: Oxford University Press.

Bram, D. (2011, April). Peran hermeneutika dalam rangka meningkatkan kualitas putusan (Kajian Putusan Hakim Nomor 31/PID.B/2009/ PN.PL.R). Jurnal Yudisial, 4(1), 46-61.

Dhami, M.K., et al. (2009). Restorative justice in prisons. Contemporary justice review, 12(4), 433-448.

Gönczöl, K, et al. (2010). European best practices of restorative justice in the criminal procedure. Hungary: Conference Publication.

Hukum Online. (2013, Mei 16). Masalah independensi hakim \& rasa keadilan masyarakat. Diakses dari http://www.hukumonline.com/klinik/ detail/c13026/masalah-independensi-hakimdan-rasa-keadilan-masyarakat.

Kant, R.R. (2011). School Management Committee Manual 2011. New Delhi: National Coalition for Education.

Kurian, G.T. (2006). World encyclopedia of police force \& correctional systems. 2nd ed. Detroit: Thomson Gale.

Liebmann, M. (2007). Restorative justice, how it works. London: Jessica Kingsley Publisher.

Masahiro, S., \& Hennessey, H. (2016, November). Current debates over restorative justice: Concept, definition, \& practice. Prison Service Journal, 228.

Setyawan, D. (2014, Juni). Menuju restorative justice dalam sistem peradilan pidana anak. Diakses dari http://www.kpai.go.id/artikel/menujurestorative-justice-dalam-sistem-peradilan-anak/.

Shidarta. (2007). Utilitarianisme. Jakarta: UPT Penerbitan Universitas Tarumanegara.

Susanto, A.F. (2011, April). Potret buram anak perempuan Indonesia (Kajian Putusan No. 1210/PID.B/2007/P.N.BB tentang Incest. Jurnal Yudisial, 4(1), 75-88.

The Canadian Resource Centre for Victim of Crime. (2011). Restorative justice in Canada, what victims should know? Ontario: The Canadian Resource Centre for Victim of Crime.

Wigjnosoebroto, S. (2013). Hukum konsep \& metode. Malang: Setara Press.

Yuster, et al. (2006). Manual for the measurement of juvenile justice indicators. New York: United Nations Office on Drugs and Crime. 